\title{
THE ABSORPTION OF HEXOSES FIROM THE UPPER PART OF THE SMALL INTESTINE IN MAN
}

\author{
By JUDA GROEN 1 \\ (From the Thorndike Memorial Laboratory, Second and Fourth Medical Services (Harvard), \\ Boston City Hospital, and the Department of Medicine, Harvard Medical \\ School, Boston)
}

(Received for publication November 28, 1936)

The most direct approach to the study of absorption from the gastro-intestinal tract, both in man and in animals, is offered by those methods that make use of the introduction of a known amount of a test substance into the alimentary canal, followed by the estimation of what is left after a definite period of time. Cori $(1,2)$, working with animals, introduced the substance by stomach tube, killed the animal after a certain time, and determined the amount of the substance still present in the digestive tract at that moment. His technique has been adopted by many other physiologists. The procedure of intestinal intubation with the aid of a rubber tube having a collapsible balloon at its lower end developed by Miller and Abbott (3) offered an opportunity for a direct study of intestinal absorption in man. The present paper gives the results of a study of the absorption of three hexoses: glucose, galactose and levulose in normal adult human subjects. Similar studies, carried out on patients with intestinal disturbances will be reported elsewhere.

\section{METHODS}

A complete description of the tube is given by Miller and Abbott (3) and Owles (4). Their technique has been modified for the present investigation.

Principles. Miller and Abbott have recommended the use of a three-lumen tube furnished with two balloons for absorption experiments. They contend that in studying absorption in segments of small intestine that are isolated between two balloons an objective measurement of the process of absorption per se is obtained. On the other hand, it seemed to us that under these circumstances a free flow of gastric juice and bile into the segment that is being studied cannot take place, which might interfere with the normal conditions of absorption. Moreover, in working with hypertonic solutions a considerable secretion of fluid takes place from the intestinal wall into the lumen. The accumulation of fluid tends to distend an isolated loop which may give rise to pain and leakage.

1 Rockefeller Foundation Fellow, 1935-1936.
For these reasons, we have chosen a tube with two lumina and only one balloon.

The tube is furnished with metal markers at certain points which enable the investigator to ascertain its exact position on the $x$-ray screen or on an $x$-ray plate. One of the lumina leads into the collapsible rubber balloon attached at the end of the tube. Once the tip of the tube reaches the jejunum the inflation of the balloon with air to the correct pressure will block off the intestine, so making the duodenum and upper part of the jejunum a cavity closed at the lower end. The second lumen of the tube leads into a number of holes that open above the balloon; through these the test substance is introduced into the intestine. The test substance is thus in contact with the mucous membrane of the duodenum and the upper part of the jejunum between the pylorus and the balloon. It is allowed to remain there for a certain time, after which what is left is recovered by aspiration and washing.

Miller and Abbott (3) observe their subjects under the fluoroscope during the introduction of the tube. We have preferred to introduce the tube first by the routine procedure customary for intubation of the duodenum. The subject swallows the tube quickly until the $55 \mathrm{~cm}$. mark is reached, when the tip of the tube is in the stomach. The subject then lies down on the right side and is instructed to continue swallowing the tube slowly until the tip of the tube has reached the desired position in the jejunum at about 125 to $130 \mathrm{~cm}$. from the teeth. The time required for the passage of the tip of the tube to the desired point varies between 2 and 4 hours. The main delay occurs at the pylorus and the duodeno-jejunal flexure.

The criteria that furnish the indications that the tube has entered the jejunum are: (1) the length of the tube swallowed without kinking by the subject; (2) the appearance of bile on aspiration through the tube; (3) the localization of the pain experienced by the subject on inflation of the balloon. Usually, so long as the balloon is still inside the stomach, the subject feels only a vague sensation; if the balloon is inside the duodenum, most subjects localize the pain on inflation very definitely in the median epigastric region, a few in the right hypochondrium. After the tip of the tube has passed the duodeno-jejunal flexure, the localization becomes much more variable: the pain is experienced in the left hypochondrium, the umbilical region or the lower part of the abdomen, either to the right or left. Without claiming an absolute validity for these subjective localizations 
(which can never take the place of an $x$-ray control), we have obtained from them very useful information. The subject is now examined either by fluoroscopy or by exposure of an x-ray plate. By this means the exact position of the tube is definitely ascertained. This simplification saves the subjects much exposure to radiation and it observed to pass either backward through the pylorus or forward past the bailoon (Figure 1). We feel confident therefore that no regurgitation took place during the absorption tests to be described, provided the subjects were quiet, the amount of fluid introduced not too great, and the pressure in the balloon not too high.

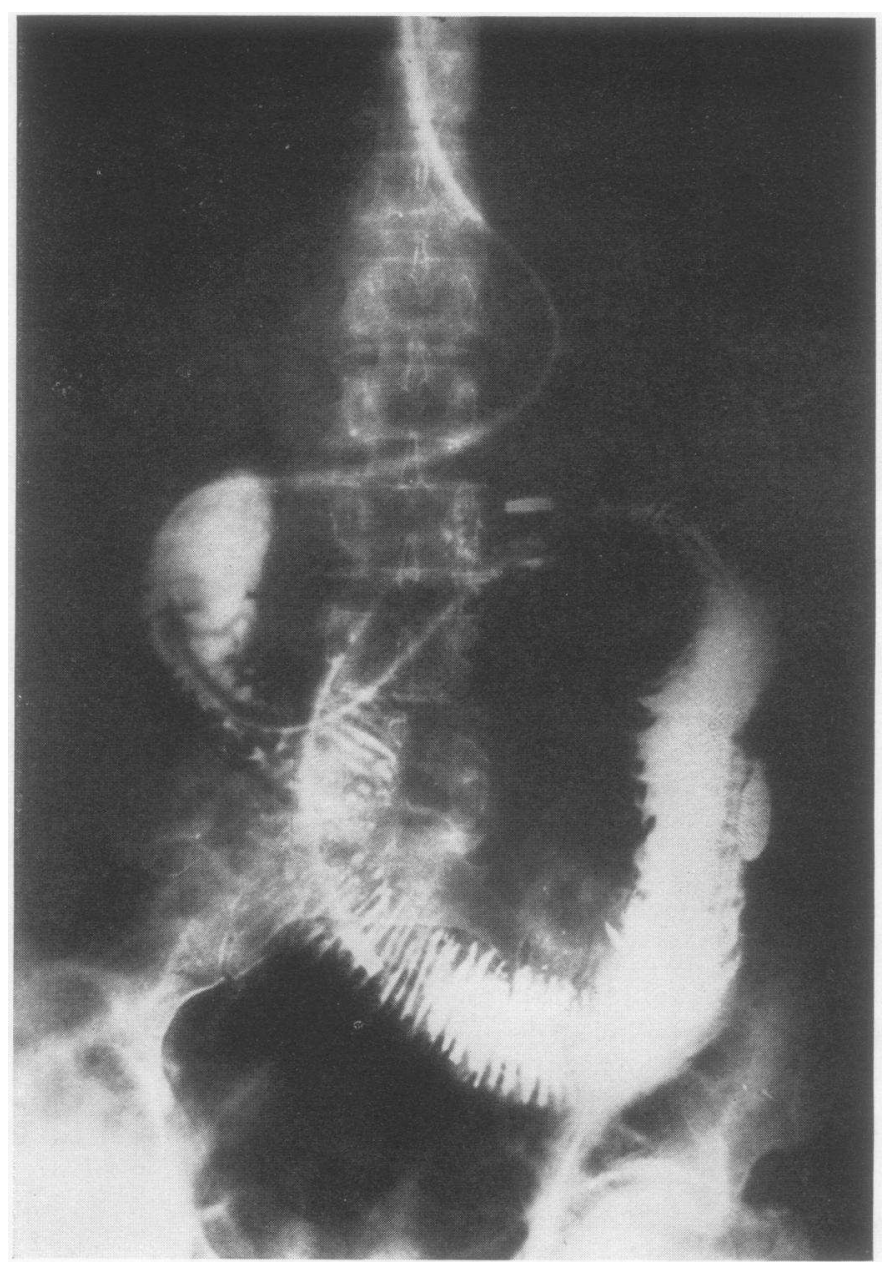

Fig. 1. The Tube in Situ

The barium is seen to occupy the duodenum and upper part of the jejunum.

also makes the method available for investigators who have not the equipment necessary for observing subjects continuously under the fluoroscope. Moreover, it makes the intubation applicable to patients who are too ill to stand much handling.

Controls. The question of regurgitation into the stomach during the absorption tests required special consideration. In two experiments in which barium sulphate was added to a concentrated glucose solution, the fluid could be seen under the fluoroscope moving up and down and spreading out over the whole of the area between the pylorus and the neck of the balloon. No barium was
In every experiment, some of the stomach contents was aspirated and tested for sugar. If regurgitation had taken place the experiment was discarded. Leakage downward was adequately prevented if the pressure in the balloon was kept above $25 \mathrm{~cm}$. of water. This has been demonstrated by Miller and Abbott (3), Owles (4) and ourselves by the introduction into the gut of non-absorbable substances such as vital red or ferric ammonium citrate that could be recovered quantitatively by aspiration 30 minutes later.

Subjects. After the first tests, the subjects were often able to swallow the tube to the desired point entirely by 
themselves. All subjects used for this study were adults, volunteers, varying in age between 18 and 60 years. One of the subjects $(S)$ was a woman; the others were men. All were in a healthy state of nutrition. Their weights varied from $120(\mathrm{~S})$ to 175 pounds $(\mathrm{M})$. Two subjects ( $T$ and F) were epileptics, but as far as could be ascertained by routine physical and chemical examinations, were without any sign of "organic disease." No significant differences in absorption that could be attributed to differences in age, sex, or weight of the subjects were discovered. The absorption values in these individuals seemed sufficiently constant within the limits of experimental error to exclude the presence of individual peculiarities.

Procedure. By preliminary experiments a period sufficiently long to permit absorption of several grams of sugar was determined. The following standard technique was then adopted, in which the time of the absorption and the time required for aspiration and washing out of the solution were kept constant in every experiment. The fasting subject was instructed to swallow the tube until the tip of the tube appeared to be in the correct location by the criteria described above. An x-ray picture was then made to ascertain the exact position of the tip inside the intestine and to determine the distance between the pylorus and the neck of the balloon. This length was measured from the position inside the intestine of the metal markers on the tube. Since, as will be shown later, the absorption rate varies in direct proportion with the length of intestinal surface area exposed (Table II), all our experiments, when other variables were being studied, were carried out with a constant length $(50 \mathrm{~cm}$.) of this "absorption area." Whenever it was not possible to adjust the tube to just this length a correction was used in the calculation of the final results. After x-ray control had given evidence that the tube was in the desired position, the balloon was inflated with air to a pressure of 25 to $40 \mathrm{~cm}$. of water and the maintenance of this pressure controlled. The subject was instructed to lie quietly and avoid coughing.

One hundred cc. of sugar solution were then introduced slowly under constant control of the pressure in the balloon, followed by about $15 \mathrm{cc}$. of water to force the solution from the dead space in the tube down into the gut. The introduction of the solution took about 5 minutes. All this time the pressure in the balloon was watched and, if necessary, readjusted to the level of 25 to $40 \mathrm{~cm}$. of water.

Exactly half an hour after the beginning of the injection of the solution, the intestinal content was aspirated with an ordinary syringe. The period between introduction and aspiration will be referred to as "absorption time." Aspiration took about 5 minutes, after which a thorough washing followed to insure complete recovery of the material introduced. The washing was carried out by making the subject drink 100 cc. of water four times at 5-minute intervals. This fluid could usually be aspirated from the jejunum 6 to 12 minutes after it had been swallowed. On its way downward it washed out the re- maining sugar solution. Half an hour after the first withdrawal of the solution from the intestine, Benedict's test for the presence of sugar in the washings was invariably negative. At that time the balloon was deflated and the tube carefully withdrawn.

Intestinal contents and subsequent washings were collected separately and analyzed for sugar both by polarimetry (after precipitation with lead acetate) and by a reduction method (Benedict's). Usually the results agreed within fairly narrow limits. Chlorides, if desired, were determined by Whitehorn's method (5). In many experiments a capillary blood sugar curve was determined along with the absorption test, using the micro method of Folin (6).

\section{RESULTS}

\section{Influence of concentration on absorption rate} of glucose. In this series of 11 experiments the length of "absorption area" (that is, the distance from the pylorus to the neck of the balloon) was $50 \mathrm{~cm}$. in all tests. The "absorption time" was half an hour. The washing out of the sugar solution also took half an hour. The quantity of solution introduced was always $100 \mathrm{cc}$. The only variable in the series was therefore the concentration, respectively $5,7.5,10,15$, and 20 per cent of glucose. The results are given in Table $\mathrm{I}$. In the

TABLE I

Influence of concentration on the absorption of glucose by a standard area of $50 \mathrm{~cm}$. length of upper small intestine

\begin{tabular}{|c|c|c|c|}
\hline \multirow{2}{*}{ Subject } & \multirow{2}{*}{ Date } & \multicolumn{2}{|c|}{ Quantity of glucose } \\
\hline & & Introduced & Absorbed \\
\hline $\begin{array}{l}\mathbf{M} \\
\mathbf{M}\end{array}$ & $\begin{array}{r}16,1936 \\
5,1936\end{array}$ & $\begin{array}{r}\text { grams } \\
5.0 \\
7.5\end{array}$ & $\begin{array}{c}\text { grams } \\
4.50 \\
6.17\end{array}$ \\
\hline $\begin{array}{l}\mathbf{M} \\
\mathbf{E} \\
\mathbf{M} \\
\mathbf{M} \\
\mathbf{M} \\
\mathbf{M} \\
\mathbf{M} \\
\mathbf{S} \\
\mathbf{E}\end{array}$ & $\begin{array}{l}\text { November } 16,1935 \\
\text { April 15, } 1935 \\
\text { November 18, } 1935 \\
\text { December 20, } 1935 \\
\text { December 23, } 1935 \\
\text { December 28, } 1935 \\
\text { November } 9,1935 \\
\text { December 5, } 1935 \\
\text { November 29, } 1935\end{array}$ & $\begin{array}{l}10.0 \\
10.0 \\
15.0 \\
15.0 \\
15.0 \\
15.0 \\
20.0 \\
20.0 \\
20.0\end{array}$ & $\begin{array}{l}7.77 \\
9.00 \\
8.30 \\
7.16 \\
7.00 \\
7.85 \\
7.30 \\
8.50 \\
7.03\end{array}$ \\
\hline \multicolumn{2}{|c|}{ Average of 9 experiments...... } & 10 to 20 & 7.77 \\
\hline
\end{tabular}

first two experiments in which the concentration was relatively low, there was a definite increase in the rate of absorption with the concentration. However, in 9 experiments in which the concentration was 10 per cent or over, the quantity of glucose absorbed was independent of the amount 
introduced. Apparently the intestine absorbs these concentrated solutions at a uniform rate above which no increase is possible. Under these conditions the amount of glucose absorbed from an area of upper intestine between the pylorus and a point $50 \mathrm{~cm}$. lower down varied from 7.03 to 9.0 grams in the 9 experiments recorded here. The average was 7.77 grams.

In comparing these figures with those obtained by other workers, it should be borne in mind that although the so-called "absorption time" in these experiments was one-half hour, the actual time available for absorption was longer, as some absorption must have gone on during the time when the glucose solution was being washed out. Thus from these observations an idea of the actual amount of glucose absorbed per unit of time can only be derived by approximation. Usually after 40 to 45 minutes the greater part of the sugar solution had been recovered from the intestine. Assuming that all absorption had taken place by that time, one may then estimate that the absorption of glucose from a concentrated solution in a loop of human upper intestine of $50 \mathrm{~cm}$. length goes on at a rate of 7.77 grams per 40 to $45 \mathrm{~min}$ utes or 10.36 to 11.65 grams per hour.

TABLE II

Influence of absorption area on absorption of glucose

\begin{tabular}{|c|c|c|c|c|c|}
\hline \multirow{2}{*}{$\begin{array}{l}\text { Sub- } \\
\text { jetct }\end{array}$} & \multirow{2}{*}{ Date } & \multirow{2}{*}{$\begin{array}{l}\text { Length } \\
\text { of ab- } \\
\text { sorp- } \\
\text { tion } \\
\text { area }\end{array}$} & \multicolumn{2}{|c|}{$\begin{array}{c}\text { Quantity of } \\
\text { glucose }\end{array}$} & \multirow{2}{*}{$\begin{array}{l}\text { Absorption } \\
\text { calculated } \\
\text { per } 50 \mathrm{~cm} . \\
\text { length }\end{array}$} \\
\hline & & & $\begin{array}{l}\text { Intro- } \\
\text { duced }\end{array}$ & $\begin{array}{c}\text { Ab- } \\
\text { sorbed }\end{array}$ & \\
\hline $\begin{array}{l}\mathbf{S} \\
\mathbf{S} \\
\mathbf{M}\end{array}$ & $\begin{array}{l}\text { November } 26,1935 \\
\text { December } 2,1935 \\
\text { March 12, } 1936 \\
\text { Average of } 4 \\
\text { experiments }\end{array}$ & $\begin{array}{r}c m . \\
\$ 30 \\
40 \\
445 \\
4450 \\
5\end{array}$ & $\begin{array}{c}\text { grams } \\
10 \\
15 \\
15 \\
15\end{array}$ & $\begin{array}{r}\text { grams } \\
5.40 \\
7.00 \\
7.73 \\
7.71\end{array}$ & $\begin{array}{c}\text { grams } \\
9.00 \\
8.40 \\
8.66 \\
7.71\end{array}$ \\
\hline $\begin{array}{l}\mathbf{F} \\
\mathbf{E}\end{array}$ & \begin{tabular}{|lr} 
March & 8,1936 \\
April & 30,1936 \\
December & 13,1935
\end{tabular} & $\begin{array}{r}55 \\
760 \\
70\end{array}$ & $\begin{array}{l}15 \\
15 \\
15\end{array}$ & $\begin{array}{r}9.35 \\
9.29 \\
10.20\end{array}$ & $\begin{array}{l}8.50 \\
7.74 \\
7.30\end{array}$ \\
\hline \multicolumn{2}{|c|}{ Average for 6 subjects... } & & & & 8.18 \\
\hline
\end{tabular}

Length of absorption area. Table II shows the results of a second series of 9 experiments in which absorption time and the quantity of glucose introduced (15 grams) being kept constant, the only variable was the length of duodenum and jejunum that took part in the absorption. In these experiments the length of the absorp- tion area varied from $40 \mathrm{~cm}$. to $70 \mathrm{~cm}$. In one other experiment, 10 grams of glucose was admitted to a length of $30 \mathrm{~cm}$. of intestine. The results show within the limits of the experimental error a direct proportional relationship between the length of intestine that takes part in the absorption and the quantity of glucose absorbed. If the results are calculated for a standard absorption area of $50 \mathrm{~cm}$. they fall within the limits of variation shown in Table I. The minimum absorption calculated in this way was 7.30 grams, the maximum 9.00 grams, the average value 8.18 grams.

TABLE III

Influence of $p H$ on absorption of glucose

\begin{tabular}{|c|c|c|c|c|}
\hline \multirow{2}{*}{$\begin{array}{l}\text { Sub- } \\
\text { ject }\end{array}$} & \multirow{2}{*}{ Date } & \multicolumn{2}{|c|}{ Quantity of glucose } & \multirow{2}{*}{$\underset{\text { (calculated) }}{\mathbf{p H}}$} \\
\hline & & Introduced & Absorbed & \\
\hline $\mathbf{M}$ & $\begin{array}{l}\text { Average of } 4 \\
\text { experiments }\end{array}$ & $\begin{array}{c}\text { grams } \\
15\end{array}$ & $\begin{array}{c}\text { grams } \\
7.71\end{array}$ & 7 \\
\hline $\begin{array}{l}\mathbf{M} \\
\mathbf{M} \\
\mathbf{M}\end{array}$ & $\begin{array}{l}\text { March 3, } 1936 \\
\text { March 4, } 1936 \\
\text { March 2, } 1936 \\
\text { April 22, } 1936\end{array}$ & $\begin{array}{l}15 \\
15 \\
15 \\
15\end{array}$ & $\begin{array}{l}6.86 \\
6.03 \\
6.79 \\
6.17\end{array}$ & $\begin{array}{r}12 \\
12 \\
2 \\
2\end{array}$ \\
\hline
\end{tabular}

Influence of $p H$. Table III shows the results of a third series of 4 experiments upon the influence of the $\mathrm{pH}$ upon the absorption of glucose. All conditions were the same as in the first series of experiments but for the addition of $10 \mathrm{cc}$. of $\mathrm{N} / 10$ normal $\mathrm{NaOH}$ or of $10 \mathrm{cc} \mathrm{N} / 10$ normal $\mathrm{HCl}$ to $100 \mathrm{cc}$. of the 15 per cent glucose solution. The results show that in each case the absorption of the glucose solution was somewhat diminished by altering the reaction away from the neutral point. At $\mathrm{pH} 12$ the absorption values were 6.03 and 6.86, respectively, at $\mathrm{pH} \mathrm{2,6.17}$ and 6.79, compared with the average of 7.71 for control experiments at neutral reaction.

The capacity of the duodenum to buffer its content to a neutral reaction was well brought out by these observations. The fasting content of the upper part of the intestine has a neutral reaction ( $\mathrm{pH} 7.0$ to 7.1). The intestinal contents aspirated after half an hour were also neutral, irrespective of whether acid or alkaline glucose solutions had been introduced. 
TABLE IV

Influence of preceding dietary regimen on absorption of glucose

\begin{tabular}{|c|c|c|c|c|}
\hline \multirow{2}{*}{$\begin{array}{l}\text { Sub- } \\
\text { ject }\end{array}$} & \multirow{2}{*}{ Date } & \multicolumn{2}{|c|}{$\begin{array}{l}\text { Quantity of } \\
\text { glucose }\end{array}$} & \multirow{2}{*}{ Remarks } \\
\hline & & $\begin{array}{l}\text { Intro- } \\
\text { duced }\end{array}$ & $\begin{array}{c}\text { Ab- } \\
\text { sorbed }\end{array}$ & \\
\hline $\mathbf{M}$ & $\begin{array}{l}\text { November } 10,1935 \\
\text { December } 28,1935\end{array}$ & $\begin{array}{c}\text { grams } \\
15 \\
15\end{array}$ & $\begin{array}{c}\text { grams } \\
8.30 \\
7.85\end{array}$ & $\begin{array}{l}\text { Vegetarian diet for several } \\
\text { years } \\
\text { After } 14 \text { days on mixed diet }\end{array}$ \\
\hline $\begin{array}{l}\mathbf{E} \\
\mathbf{E} \\
\mathbf{E}\end{array}$ & $\begin{array}{l}\text { December 13, 1935 } \\
\text { April 26, } 1935 \\
\text { April 30, } 1935\end{array}$ & $\begin{array}{l}15 \\
15 \\
15\end{array}$ & $\begin{array}{l}7.30 \\
7.34 \\
7.74\end{array}$ & $\begin{array}{l}\text { Mixed diet } \\
\text { After } 4 \text { days on ketogenic } \\
\text { diet } 8 \text { days on ketogenic } \\
\text { After } 8 \text { days } \\
\text { diet }\end{array}$ \\
\hline $\mathbf{T}$ & March 12, 1936 & 15 & 8.66 & After 2 days' starvation \\
\hline$\underset{\mathbf{F}}{\mathbf{F}}$ & $\begin{array}{l}\text { August 15, } 1936 \\
\text { August 19, } 1936 \\
\text { August 29, } 1936\end{array}$ & $\begin{array}{l}15 \\
15 \\
15\end{array}$ & $\begin{array}{l}8.50 \\
9.36 \\
8.10\end{array}$ & $\begin{array}{l}\text { Mixed diet } \\
\text { After } 4 \text { days' starvation } \\
\text { After } 10 \text { days of diet low in } \\
\text { carbohydrate and rich in } \\
\text { fat and protein }\end{array}$ \\
\hline
\end{tabular}

Influence of preceding diet and of starvation. Table IV summarizes the results of a fourth series of 9 experiments undertaken to investigate the possible influence of the nutritional condition of the subject on the absorption rate of the glucose solution. The amount of glucose introduced was always 15 grams in $100 \mathrm{cc}$. of water, the absorption length $50 \mathrm{~cm}$., the absorption and washing time thirty minutes each. Under these circumstances it appeared that the absorption was essentially the same whether the subjects followed a vegetarian regimen or had taken a diet rich in animal protein and fat. One of the subjects (E) took a ketogenic diet that contained 25 grams of carbohydrate for 8 days, after which time the urine gave a positive reaction for acetone. The absorption test gave a normal result.

The effect of complete starvation was tested on two epileptic subjects ( $T$ and F). Patient $T$ starved for 48 hours, and Patient $F$ for 96 hours. The fluid intake during the starvation was not restricted. Both showed a high normal absorption for glucose after this period.

Nature of sugar. The effect of the nature of the sugar upon the absorption under standard conditions was next investigated. Table V contains the results of a fifth series of 8 experiments in which galactose solutions of various strength were tested. The conditions of the experiments were the same as for those on glucose absorption. The figures in Table $\mathrm{V}$ show that above a concentration of 15 per cent the absorption rate is
TABLE $\mathbf{v}$

Quantities of galactose absorbed by a $50 \mathrm{~cm}$. length of upper small intestine

\begin{tabular}{|c|c|c|c|}
\hline \multirow{2}{*}{ Subject } & \multirow{2}{*}{ Date } & \multicolumn{2}{|c|}{ Quantity of galactose } \\
\hline & & Introduced & Absorbed \\
\hline $\begin{array}{l}\text { M } \\
\text { M } \\
\text { E } \\
\text { S } \\
\mathbf{N} \\
\mathbf{G} \\
\mathbf{M} \\
\mathbf{S}\end{array}$ & $\begin{array}{l}\text { November 25, } 1935 \\
\text { November 29, } 1935 \\
\text { December } 31,1935 \\
\text { December 10,1935 } \\
\text { February 10,1936 } \\
\text { February 14, } 1936 \\
\text { December } 3,1935 \\
\text { December } 17,1935\end{array}$ & $\begin{array}{c}\text { grams } \\
15 \\
15 \\
15 \\
15 \\
15 \\
15 \\
20 \\
20\end{array}$ & $\begin{array}{r}\text { grams } \\
9.95 \\
10.66 \\
8.19 \\
9.61 \\
11.00 \\
8.62 \\
8.70 \\
8.88\end{array}$ \\
\hline \multicolumn{2}{|c|}{ Average.. } & 15 to 20 & 9.45 \\
\hline
\end{tabular}

independent of the concentration. The actual amount of galactose absorbed appeared to be larger in the same unit of time than that of glucose, the average value being 9.45 grams, varying from a minimum of 8.19 to a maximum of 11.0 under the standard conditions. An approximation of the absorption per unit of time based on the same principles as used above for glucose would lead to an estimate of 12.60 to 14.17 grams per hour as the rate of absorption of galactose from a concentrated solution in a loop of intestine of $50 \mathrm{~cm}$. length.

TABLE VI

Quantities of levulose absorbed by a $50 \mathrm{~cm}$. length of upper small intestine

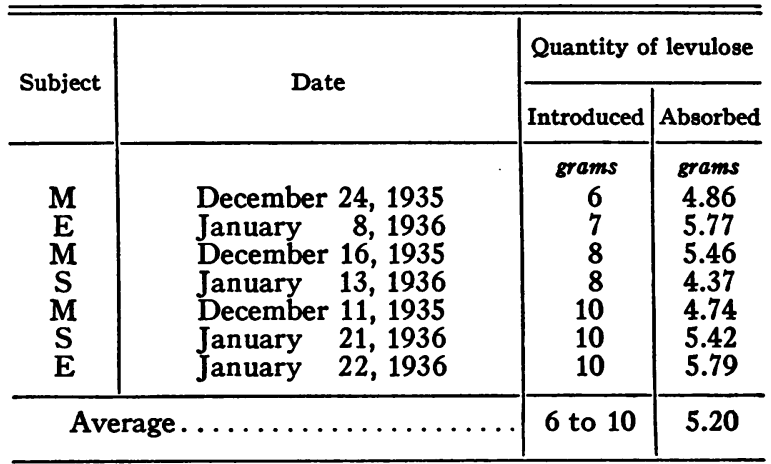

Table VI shows the results of a sixth series of 7 experiments upon the absorption of levulose. The absorption rate appears to be constant for solutions above 6 per cent in concentration. The absorption of levulose is definitely slower than that of glucose or galactose, varying from 4.37 to 5.79 grams under standard conditions. The av- 
erage value was 5.20 grams. Approximation would yield an absorption rate of 6.93 to 7.80 grams of levulose per hour from a $50 \mathrm{~cm}$. length of intestine.

It will be noted that the maximum absorption rate in the case of levulose occurred at a lower concentration ( 6 per cent) than that of glucose (10 per cent). Apparently the critical level above which the absorption rate becomes uniform is not determined by the osmotic concentration and may be a characteristic property of every individual sugar.

Influence of the absorption time. In a seventh series of 4 experiments, all carried out with galactose on the same subject, the "absorption time" was varied to respectively, $0,15,30$, and $45 \mathrm{~min}$ utes with otherwise standard conditions. The washing time was kept constant at one-half hour in all instances. The results are shown in Table VII. As could be expected, a direct, almost

TABLE VII

Influence of "absorption time" upon absorption of galactose

\begin{tabular}{|c|c|c|c|c|}
\hline \multirow{2}{*}{ Subject } & \multirow{2}{*}{ Date } & \multicolumn{2}{|c|}{$\begin{array}{c}\text { Quantity of } \\
\text { galactose }\end{array}$} & \multirow{2}{*}{$\begin{array}{c}\text { Absorp- } \\
\text { tion } \\
\text { time }\end{array}$} \\
\hline & & $\begin{array}{l}\text { Intro- } \\
\text { duced }\end{array}$ & $\begin{array}{c}\text { Ab- } \\
\text { sorbed }\end{array}$ & \\
\hline $\begin{array}{l}\mathbf{E} \\
\mathbf{E} \\
\mathbf{E}\end{array}$ & $\begin{array}{l}\text { March } 11,1936 \\
\text { February } 19,1936 \\
\text { December } 31,1935 \\
\text { December } 18,1935\end{array}$ & $\begin{array}{c}\text { grams } \\
15 \\
15 \\
15 \\
15\end{array}$ & $\begin{array}{r}\text { grams } \\
2.41 \\
5.73 \\
8.19 \\
13.00\end{array}$ & $\begin{array}{c}\text { minutes } \\
0 \\
15 \\
30 \\
45\end{array}$ \\
\hline
\end{tabular}

linear relationship was found between the quantity absorbed and the time allowed for absorption. In the experiment in which the absorption time was "zero," the aspiration of the solution was started immediately after it had been introduced. All the absorption that took place must have occurred, therefore, during the injection of the solution (5 minutes) and the "washing time" (30 minutes).

This series of experiments also furnishes data from which a more exact idea of the absolute value for the absorption rate of galactose can be obtained. By deducting the figure for " 0 " minute absorption time from that for the 15-minute period, etc., values for the quantity absorbed during exactly 15 and 30 minutes can be obtained. These values vary from 2.46 to 4.81 grams, with an average of 3.44 grams per 15 minutes or 13.76 grams per hour. This agrees fairly well with the values of 12.60 to 14.17 that have been arrived at by approximation.

Osmotic relationships. The quantity of fluid recovered one-half hour after the introduction of $100 \mathrm{cc}$. of the concentrated sugar solution into the intestine was always larger than the amount introduced and varied between 140 and $250 \mathrm{cc}$., with an average of $200 \mathrm{cc}$. Apparently, while sugar was being absorbed, fluid had moved into the lumen of the intestine. Though in part probably derived from the small intestinal wall, bile, pancreatic juice, and gastric juice may have flowed into the intestine and contributed to the dilution of the test solution. During the next half hour, while the subjects were drinking a total of $400 \mathrm{cc}$. of water, another volume of fluid was collected. The washings varied in volume from 200 to $400 \mathrm{cc}$., dependent on the amount of water that was retained inside the stomach.

The concentration of glucose found in the intestinal contents after half an hour varied from 2.11 to 3.24 grams per $100 \mathrm{cc}$., with an average of 2.50 per cent. The concentration of glucose was apparently reduced to about half its isotonic concentration (5.4 per cent). This may seem strange at first, as one would not expect a dilution below isotonicity. It should be remembered, however, that the normal duodeno-jejunal juice contains chloride in almost the same concentration as the blood plasma (in our experience between 279 and $475 \mathrm{mgm}$. per $100 \mathrm{cc}$; ; according to Karr and Abbott (7) between 178 and 528 mgm. per $100 \mathrm{cc}$.). The chlorides, together with the bicarbonate, maintain the normal osmotic pressure of the intestinal juice. The dilution of a hypertonic glucose solution inside the intestine will go on, therefore, until the concentration of glucose plus the concentration of the other constituents together make up isotonicity. That this holds true was brought out by determination of the chloride in the intestinal content. In the fluid aspirated one-half hour after the introduction of the glucose solution, the chloride concentration was markedly lower than before the introduction of the glucose. The values varied between 212 and $287 \mathrm{mgm}$. per $100 \mathrm{cc}$. (Table VIII). Moreover, there was an almost complete inversely proportional relationship between the glucose and 
TABLE VIII

Concentration of glucose and chloride in intestinal content 30 minutes after introduction of $100 \mathrm{cc} .15$ per cent glucose solution

\begin{tabular}{|c|c|c|c|}
\hline$\underset{\text { ject }}{\text { Sub- }}$ & Date & Glucose & Chloride \\
\hline $\begin{array}{l}\mathbf{E} \\
\mathbf{F} \\
\mathbf{O} \\
\mathbf{E} \\
\mathbf{M} \\
\mathbf{E} \\
\mathbf{S} \\
\mathbf{F} \\
\mathbf{F} \\
\mathbf{F}\end{array}$ & \begin{tabular}{lr}
\multicolumn{2}{c}{1986} \\
September 29 \\
April & 23 \\
September & 25 \\
April & 27 \\
May & 19 \\
April & 30 \\
April & 28 \\
August & 19 \\
August & 14 \\
May & 12
\end{tabular} & $\begin{array}{c}\text { grams per } \\
100 \text { cc. } \\
3.24 \\
3.14 \\
2.57 \\
2.52 \\
2.48 \\
2.26 \\
2.26 \\
2.22 \\
2.14 \\
2.11\end{array}$ & $\begin{array}{c}\text { mgm. per } \\
100 \text { cc. } \\
212 \\
219 \\
229 \\
224 \\
228 \\
229 \\
243 \\
287 \\
287 \\
271\end{array}$ \\
\hline \multicolumn{2}{|c|}{ Average. } & 2.49 & 243 \\
\hline
\end{tabular}

chloride concentration, chlorides being higher in the fluids with the lower glucose content.

If we express both glucose and chloride concentration in milliequivalents and assume that all the cations present are monovalent, we can calculate the sum of the osmotic concentrations of glucose, the chlorides and the cations together. For this purpose we simply multiply the chloride concentration by 2 , and add this to the glucose concentration. Table IX shows the figures ob-

TABLE IX

Glucose and chloride concentration and their combined osmotic pressure in intestinal content at end of absorption period

\begin{tabular}{|c|c|c|c|c|}
\hline $\begin{array}{l}\text { Sub- } \\
\text { ject }\end{array}$ & Date & $\begin{array}{l}\text { Glucose } \\
\text { concen- } \\
\text { tration }\end{array}$ & $\begin{array}{l}\text { Chloride } \\
\text { concen- } \\
\text { tration }\end{array}$ & $\begin{array}{l}\text { Combined osmotic } \\
\text { pressure of glucose, } \\
\text { chlorides and their } \\
\text { monovalent cations }\end{array}$ \\
\hline \multirow{12}{*}{$\begin{array}{l}\mathbf{E} \\
\mathbf{F} \\
\mathbf{O} \\
\mathbf{E} \\
\mathbf{M} \\
\mathbf{E} \\
\mathbf{S} \\
\mathbf{F} \\
\mathbf{F} \\
\mathbf{F}\end{array}$} & 1986 & $\begin{array}{l}\text { m.eq. per } \\
100 \text { cc. }\end{array}$ & $\begin{array}{l}\text { m.eq. per } \\
100 \text { cc. }\end{array}$ & $\begin{array}{l}\text { "milliosmoles" per } \\
100 \text { cc. }\end{array}$ \\
\hline & September 29 & 18.00 & 5.99 & 29.98 \\
\hline & April $\quad 23$ & 17.45 & 6.16 & 29.77 \\
\hline & September 25 & 14.28 & 6.45 & 27.18 \\
\hline & April $\quad 27$ & 14.00 & 6.31 & 26.62 \\
\hline & May & 13.78 & 6.42 & 26.60 \\
\hline & April & 12.56 & 6.46 & 25.48 \\
\hline & April & 12.56 & 6.85 & 26.26 \\
\hline & August & 12.34 & 8.09 & 28.52 \\
\hline & August & 11.89 & 8.09 & 28.07 \\
\hline & May & 11.72 & 7.64 & 27.00 \\
\hline & Average. . & 13.86 & 6.84 & 27.55 \\
\hline
\end{tabular}

tained in this manner. The calculated osmotic pressure in this table is expressed as "milliosmoles" per $100 \mathrm{cc}$. There is some variation in the figures but on the whole the total concentration of glucose, plus chloride, plus cation, seems to be fairly constant, varying between 25.48 and 29.77 , with an average of 27.29 milliosmoles per $100 \mathrm{cc}$. We do not know how much carbonate was present in the intestinal content, but this can only have been of small importance (Karr and Abbott (7)). If we compare our calculated osmotic concentration with the normal osmotic concentration of blood plasma (which is about 30 milliosmoles per $100 \mathrm{cc}$.) it may be safely concluded that half an hour after the introduction of a concentrated solution of glucose the human small intestine has reestablished osmotic equilibrium between its content and the blood plasma.

Blood sugar curves. In a number of tests capillary blood sugar values were determined while glucose, galactose, or levulose was being absorbed. Not all the values obtained will be given here. Table $\mathrm{X}$ shows only the maximum, min-

TABLE $\mathbf{X}$

Blood sugar values in milligrams per $100 \mathrm{cc}$. during the absorption of hexose from the upper part of the small intestine

\begin{tabular}{c|l|c|c|c|c|c|c|c}
\hline \hline & & \multicolumn{5}{|c}{ Time after introduction of 100 cc. of } \\
solution
\end{tabular}

imum, and average values that were found fasting and at successive intervals of one-quarter hour after the introduction of the sugar solution.

(a) Glucose. In almost all instances when glucose was given the blood sugar showed a definite rise after one-quarter hour, reached a peak after one-half, three-quarters or one hour, then dropped rather steeply and reached its original value again after between one and one-half and one and three-quarter hours. The height of the peak varied between $119 \mathrm{mgm}$. per $100 \mathrm{cc}$., and $188 \mathrm{mgm}$. per $100 \mathrm{cc}$. The highest point of the average curve was $134 \mathrm{mgm}$. per $100 \mathrm{cc}$. after three-quarters of an hour. There was no definite 
relationship between the amount of glucose introduced and the height to which the blood sugar rose. It is noteworthy that although the withdrawal of the glucose solution from the intestine was started after one-half hour, the blood sugar level in many instances continued to rise and dropped only after one hour. Glycosuria during the test did not occur in any instance.

(b) Galactose. The blood sugar curves after administration of galactose through the tube did not differ materially from those when glucose was being absorbed. Apparently, although the absorption rate of galactose is greater than that of glucose the storage mechanism of the body takes care of the quantity absorbed under the conditions of our experiment. A slight galactosuria occurred in five instances.

(c) Levulose. The "glycemic" effect of this sugar was decidedly less than that of glucose or galactose. The highest blood sugar value obtained with levulose was only $125 \mathrm{mgm}$. per 100 cc. (expressed as glucose). Whether this smaller rise is caused by the slower absorption rate only or whether the tissues remove levulose from the blood at a higher speed than the other sugars cannot be decided here. No levulose appeared in the urine of any of the subjects.

\section{DISCUSSION}

The present status of our knowledge of the absorption of carbohydrates has been reviewed recently by Pierce (8). Only those points bearing directly on the results obtained in this study need therefore be discussed here.

The fundamental work of Cori (1) carried out in rats has definitely established that the absorption of a simple sugar from the intestinal tract is independent of the quantity of sugar present in the alimentary canal. It should be remembered, however, that this "law" was found by introducing concentrated solutions into the animals. The validity of Cori's law has been confirmed by Cori, Cori and Goltz (9), Holtz and Schreiber (10), Magee (11), Trimble, Carey and Maddock (12), and Verzár (13). Trimble and Maddock (14), working with dogs, made the important observation that Cori's law also applies when the glucose solution is introduced directly into the duodenum. Other investigators $(15,16)$ failed to confirm Cori's observations in detail but their results are in substantial agreement with his findings. There still exists some disagreement between investigators whether the absorption rate should best be expressed per unit of intestinal surface (16) or per kilogram of body weight $(1,12)$.

Our own results confirm Cori's law for the absorption of concentrated sugar solutions from the human small intestine. The results did not warrant a calculation of the absorption rate per kilogram body weight. The area of intestine exposed to the sugar solution appeared to be of paramount importance for the amount of sugar absorbed. The absorption rate per unit of time was constant for a given intestinal length which was assumed to be a relative measure of the surface area.

The absorption of comparatively dilute sugar solutions has been studied in animals by Nagano (17), Hewitt (18), and London and Polowzowa (19), who found that the absorption rate increased with the concentration. Abbott, Karr and Miller (20) have shown this to be equally true for the human small intestine. The few experiments undertaken by us with glucose solutions of low concentrations (Table I) confirm their observations. This does not contradict the work of Cori on the absorption of concentrated solutions. Our results brought out very definitely that above a certain concentration, which seems to be different for various sugars, the absorption proceeds at a uniform rate.

London and Polowzowa (19), and Magee and Reid (21), both working with dogs, found that a maximum absorption rate for glucose established itself at concentrations of 11.5 and 13 per cent, respectively. In our experiments the absorption rate became maximal at concentrations of 10 per cent or over.

The literature contains a few conflicting reports on the influence of the $\mathrm{pH}$ on the absorption rate of glucose $(22,23)$. From our data we cannot offer an adequate explanation for the slowing down of the absorption rate by the addition of acid or alkali to the glucose solution, as observed by us. The effect need not be specific but might be caused solely by the increase in osmotic concentration of the intestinal content (24). Apparently a neutral reaction affords optimum con- 
ditions for the absorption of glucose in the intestine, but this does not necessarily hold true for other substances. It appears that the intestine possesses an efficient mechanism for the protection of the reaction of its content, a point which has been extensively studied by Karr and Abbott (7) and Stevens (25).

Various workers have shown that the intestine absorbs different sugars at a different rate. According to Cori, the proportion of the average absorption rates of galactose, glucose, and levulose (glucose being taken as 100) in the rat can be expressed as 110:100:43. Our results yield for this relationship 122:100:67, which, considering the experimental error in both animal and human experiments, may be called a satisfactory agreement. Cori $(1,2)$, Wildbrandt and Laszt (26), Verzár (13), and Westenbrink (27) have rightly concluded that since every sugar has its individual absorption rate the process of absorption in the intestine, even of such simple compounds, cannot be a purely diffusion phenomenon, but must be an active cellular process inside the epithelium of the gut. Whatever the nature of this physiological process of sugar absorption may be $(28,29,30,31)$, it appears to be of the same nature both in animals and in man.

A comparison of the actual absorption rates in animals and in man seems hardly warranted because of the different way in which the studies have been conducted. In the animal, the substance is introduced either into the stomach or into the duodenum and then allowed to spread out over all the available intestinal area where the peristalsis will carry it. In our experiments the absorption was limited to a closed loop of intestine of $50 \mathrm{~cm}$. in length. Even so, it is interesting to note that the approximate average absorption rates of glucose per hour when calculated per kilogram body weight were:

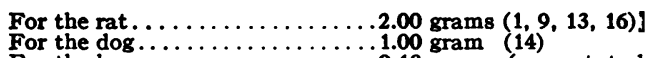

For the human...............18 gram (present study)

This furnishes another example of the higher speed at which the living processes seem to go on in the smaller animals.

Most of the blood sugar curves obtained in our experiments were only slightly lower than those observed in the capillary blood during the first hour of an ordinary glucose tolerance test, when 50 to 100 grams are given by mouth to a normal individual. We know, however, that of this large quantity only a limited portion at a time is admitted by the pylorus to the upper part of the intestine. As all other factors influencing the blood sugar curve seem to be the same in the oral and intestinal administration of the sugar, it may be concluded that even if 50 to 100 grams of glucose are given by mouth, the actual absorption is only slightly more than when 10 to 20 grams are fed into $50 \mathrm{~cm}$. of the upper part of the intestine. We have estimated the approximate rate of absorption in our experiments as 10.5 to 12 grams per hour. From the study of the rise in blood sugar during this absorption, we would venture to suggest that even when much larger quantities of glucose are given by mouth the absorption rate is only slightly more than this figure. This would imply that the time for the absorption of a glucose test meal of 50 grams would be 4 hours or somewhat less. We have little doubt that if $\mathbf{5 0}$ grams of glucose were introduced directly into the whole of the intestine the absorption would go on at a higher rate and the blood sugar would rise to higher levels (32). Given by mouth, however, the pylorus takes care that the absorption does not take place at a higher speed than the storage mechanism can keep up with (10).

\section{SUMMARY}

The absorption of glucose, galactose, and levulose from the upper part of the human small intestine has been studied by a simplified method of intestinal intubation. The results show that a given length of the human small intestine during a constant interval absorbs a constant amount of a simple sugar from a concentrated solution. Under these conditions, the amount of sugar absorbed is independent of the concentration above a certain level. The amount of sugar absorbed increases with an increase in intestinal surface. The quantity absorbed is proportional to the time allowed for absorption. The addition of dilute hydrochloric acid or sodium hydroxide to the glucose solution diminishes the amount of sugar absorbed. No influence of the immediately preceding diet or of starvation on the absorption rate could be detected. 
Glucose, galactose, and levulose have their own individual absorption rates which averaged, under the conditions of our experiments, 7.77, 9.45, and 5.20 grams, respectively, the relation being 100: 122:67. During the absorption the concentrated sugar solution inside the intestine is rapidly diluted so that after one-half hour the total osmotic concentration of the intestinal contents equals that of the blood plasma.

Blood sugar values during the absorption of the glucose, galactose, and levulose from the intestine were determined. The curves obtained indicate similar effects for glucose and galactose but a less effect upon blood sugar for levulose than for glucose.

\section{BIBLIOGRAPHY}

1. Cori, C. F., The fate of sugar in the animal body. I. The rate of absorption of hexoses and pentoses from the intestinal tract. J. Biol. Chem., 1925, 66, 691.

2. Cori, C. F., Mammalian carbohydrate metabolism. Physiol. Rev. 1931, 11, 143.

3. Miller, T. G., and Abbott, W. O., Intestinal intubation: A practical technique. Am. J. M. Sc., 1934, 187, 595.

Small intestinal intubation; experiences with double-lumened tube. Ann. Int. Med., 1934, 8, 85.

Abbott, W. O., and Miller, T. G., Intubation studies of the human small intestine. III. A technic for the collection of pure intestinal secretion and for the study of intestinal absorption. J. A. M. A., 1936, 106, 16.

4. Owles, W. To be published.

5. Whitehorn, J., A system of blood analysis. Supplement II. Simplified method for the determination of chlorides in blood or plasma. J. Biol. Chem., 1920, 45, 449.

6. Folin, O., Laboratory Manual of Biological Chemistry. New York and London, 1934, 5th ed., p. 305.

7. Karr, W. G., and Abbott, W. O., Intubation studies of the human small intestine. II. Chemical characteristics of the intestinal contents in the fasting state and as influenced by the administration of acids, of alkalies and of water. J. Clin. Invest., 1935, 14, 893.

8. Pierce, H. B., The absorption and utilization of carbohydrates. J. Nutrition, 1935, 10, 689.

9. Cori, C. F., Cori, G. T., and Goltz, H. L., On the mechanism of glucose absorption from the intestinal tract. Proc. Soc. Exper. Biol. and Med., 192829, 26, 433.
10. Holtz, F., and Schreiber, E., Kohlenhydrate auf ihrem Wege in den tierischen Organismus. Biochem. Ztschr., 1930, 224, 1.

11. Magee, H. E., The rôle of the small intestine in nutrition. Physiol. Rev., 1930, 10, 473.

12. Trimble, H. C., Carey, B. W., Jr., and Maddock, S. J., The rate of absorption of glucose from the gastro-intestinal tract of the dog. J. Biol. Chem., 1933, 100, 125.

13. Verzár, F., Die Rolle von Diffusion und Schleimhautaktivität bei der Resorption von verschiedenen Zuckern aus dem Darm. Biochem. Ztschr., 1935, 276, 17.

14. Trimble, H. C., and Maddock, S. J., The rate of absorption of glucose from the intestine of the dog. J. Biol. Chem., 1934, 107, 133.

15. Ravdin, I. S., Johnston, C. G., and Morrison, P. J., The absorption of glucose from the intestine. Am. J. Physiol., 1933, 104, 700.

16. Feyder, S., and Pierce, H. B., Rates of absorption and glycogenesis from various sugars. J. Nutrition, 1935, 9, 435.

17. Nagano, J., Zur Kenntniss der Resorption einfacher, im besonderen stereoisomerer Zucker im Dünndarm. Arch. f. d. ges. Physiol., 1902, 90, 389.

18. Hewitt, J. A., The metabolism of carbohydrates. III. The absorption of glucose, fructose and galactose from the small intestine. Biochem. J., 1924, 18, 161.

19. London, E. S., and Polowzowa, W. W., Zum chemismus der Verdauung im tierischen Körper. XXII. Verdauung und Resorption der Kohlenhydrate im Magendarmkanal des Hundes. Ztschr. f. physiol. Chem., 1908, 56, 512.

XXVII. Konzentrationsverhaltnisse bei der Resorption im Darn. Ibid., 1908, 57, 529.

20. Abbott, W. O., Karr, W. G., and Miller, T. G., Absorption of glucose from the human small intestine. Am. J. M. Sc. (Proc.), 1936, 191, 874.

21. Magee, H. E., and Reid, E., The absorption of glucose from the alimentary canal. J. Physiol., 1931, 73, 163.

22. Gellhorn, E., and Moldavsky, L. F., The effect of $\mathrm{pH}$ on the absorption of sugars. Am. J. Physiol., 1934, 109, 638.

23. Laszt, L., Die Resorption von Glucose und Xylose bei verschiedener $\mathrm{H}$-Konzentration. Biochem. Ztschr., 1935, 276, 40.

24. Cori, C. F., The rate of absorption of a mixture of glucose and galactose. Proc. Soc. Exper. Biol. and Med., 1925-26, 23, 290.

The absorption of glycine and d, 1-Alanine. Ibid., 1926-27, 24, 125.

25. Stevens, G. A., The capacity of the duodenum to neutralize, buffer and to dilute acid. Am. J. Digest. Dis. and Nutrition, 1935, 2, 288.

26. Wildbrandt, W., and Laszt, L., Untersuchungen über die Ursachen der selektiven Resorption der Zucker aus dem Darm. Biochem. Ztschr., 1933, 259, 389. 
27. Westenbrink, H. G. K. Uber die Anpassung der darmresorption an die Zusammensetzung der Nahrung. Arch. néerl. de physiol., 1934, 19, 563.

28. Lundsgaard, E., Die Wirkung von Phlorrhizin auf die Glucoseresorption. Biochem. Ztschr., 1933, 264, 221.

29. Wertheimer, E., Phloridzinwirkung auf die Zuckerresorption. Arch. f. d. ges. Physiol., 1934, 233, 514.

30. Laszt, L., Die Phosphorylierung verschiedener Zucker durch Darmschleimhautextrakte. Biochem. Ztschr., 1935, 276, 44.

31. Laszt, L., and Süllmann, H., Nachweis der Bildung von Phosphorsäureestern in der Darmschleimhaut bei der Resorption von Zuckern und Glycerin. Biochem. Ztschr., 1935, 278, 401.

32. Wachsmuth, W., Untersuchungen über den regulatorischen Reizablauf bei alimentärer Hyperglykämie. Ztschr. f. d. ges. exper. Med., 1930, 73, 645. 